\title{
Strategy For Sport Science Progressive
}

\author{
Ardo Okilanda ${ }^{1}$, Firmansyah Dlis ${ }^{2}$, Hidayat Humaid ${ }^{3}$, Dede Dwiansyah Putra ${ }^{1}$ \\ ${ }^{1}$ Physical Education Department, Universitas PGRI Palembang \\ ${ }^{2}$ Faculty of Sport, Universitas Negeri Jakarta, J1. Pemuda No.10, RT.8/RW.5, Rawamangun, Kec. Pulo \\ Gadung, Kota Jakarta Timur, Daerah Khusus Ibukota Jakarta 13220 \\ *Corresponding author email: ardo.oku@gmail.com
}

\begin{abstract}
The objective of this research is sport science campaign to society. This research used survey qualitative method conducted to students with 90 respondents made campaign task and used Instagram actively. The survey result from student's task of sport science campaign by using Instagram the students was divided into three categories, they were $15 \%$ students used Instagram no more than one hour, $30 \%$ used Instagram for two hours and more than $65 \%$ used Instagram more than three hours. Based on the result, students have a big effect to contribute society knowledge in sport science by using Instagram
\end{abstract}

Keyword: Community, Instagram, Sport Science

\section{Background}

Nowadays, almost everything are connected with electronic media. This phenomenon has positive or negative impact that will emerge in the dependence of life on technology. The domain technology focuses on internet, especially on social media, Instagram . Instagram is becoming the current popular trend in students' life. In addition, the internet is used in learning practical sports. Sports practice can be sourced from internet media as a reference in order to facilitate teaching and learning process.

Likewise, every sports competition activity carried out in various countries. This activity is presented through internet social media too. The internet is broad and easily accessible forum for all groups to be the most effective alternative in accessing various kinds of news, especially in sports competitions. The internet which stands for Interconnection Networking is a large network of computer networks that connect people and computers throughout the world, either by telephone, satellite, and other communication systems (Riyanto, 2008). Since it was introduced by the public in October 1972, the internet has experienced very rapid development. This evident is from the data of Internet World Stats ("World Internet Users Statistics and 2019 World Population Stats," t.t.) which states that the number of world internet users as of 30 June 2019 was 4,422,494,622. 
This caused is very interesting when all information quickly reaches us as users by using Instagram. Based on the data, It is known that most Instagram users are among adolescents and early adults at the age of 16-25 years. Instagram users are easily find information about sports on Instagram. As the most popular social media Instagram also has several features that can be put to good use to attract the hearts of users. Instagram is used as entertainment and information sources for every user because Instagram always giving update news.

\section{Sports}

Sport has many types in our daily lives, created from various cultural backgrounds of the world community. Lots of people are like sport from exercise until sport news in community daily life. Sport is a form of physical activity that can improve physical fitness. Sport has an important meaning in maintaining health and healing an unhealthy body (Mutohir \& Maksum, 2007). This is important because exercise provides health benefits so everyone needs sports activities.

Continuous exercise is needed especially for children. This is in line with Tangkudung \& Wahyuningtyas (2012), 'if we encourage children to develop various skills, then children may experience success in some sporting activities and will have the tendency and desire to specialize and develop further talent'. Not only for children, the parents are also had the right to get a lot of information about trusted sports.

\section{Instagram}

Lots of Instagram users in this life. It is because of there are many interesting and easily accessible things on Instagram. Instagram ca be used to find out the latest situation in the form of photos and narration through Instagram. Etymologically, Ghazali (2016) stated that Instagram is the most popular social application among smartphone users (smartphone) that originates from the words "instant" and "gram" which comes from the word telegram. This amalgamation of the word "insta-telegram" provides fast information that is managed in the form of photographs and widely shared.

Students can use Instagram to share information about sports. Considering the many benefits of an Instagram, photo is the most interesting social media seen by the public. In fact, all smartphone users can take advantage of instagram. One of the important things to look for in Instagram is information about Petanque; for example; which is not widely known by the public. Because Petanque one of the latest sport various come in Indonesia. Based on Okilanda (2018) Petanque first entered Indonesia in 2011 at the SEA Games event in Palembang. It 
means that petanque is 8 years old in Indonesia. So, it can used Instagram as one easiest way to find out deep information about this sport.

Previous research conducted by Nwankwo \& Deemua (2019), Palmer-Keenan \& Bair (2019) and Trail \& McCullough (2019) stated the importance of conducting sports campaigns both in the domains of education, society and sports organizations. Nwankwo \& Deemua (2019) in the European Journal of Physical Education and Sport Science writes about sports as a proactive strategy for the development of education. In the journal revealed that the increase in sports activities in the education domain is by linking it to the education curriculum at each level. This research finds various ways that sports can be used to improve learning in order to achieve educational goals. This research highlights how exercise can affect learners, learning experiences, materials and the environment. Nwankwo \& Deemua (2019), argued that sports affect almost every aspect of human life that has a positive impact, sports must be utilized for educational development. Exercise will ensure an increase in periods of physical activity at school and encourage active life at home which will result in a positive lifestyle among the people. The role of education in society has made its development an on-going process, therefore the collaboration needed must be used to ensure success. Nwankwo \& Deemua, (2019), recommend that: Sports must be integrated in every field of educational curriculum with adequate time allocated for sports activities. Participation in sports as part of the education curriculum must be made compulsory in educational institutions. The government must conduct an enlightenment campaign about the need for education through sports.

Furthermore, Palmer-Keenan \& Bair (2019), wrote about Campaigns to Increase Physical Activity Among Low-Income, Urban, Diverse, Inactive Youth. This research was written in the Journal of Nutrition Education and Behavior (Elsavier). The data in this study involved low-income, urban, ethnically diverse, inactive youth. This study used a formative descriptive analysis with the results of 5 focus group adolescents $(n=31), 58 \%$ of whom were Hispanic, $23 \%$ of whom were African American, and 19\% were of mixed race. To be attractive, physical activities (1) must be fun (for example, dancing, with friends and family) and (2) must be comfortable (indoors, not sweaty, not physically competitive or embarrassing), and (3) they must be promoted by cool people and colleagues. The findings in this study are that nutrition and health educators and social marketers are advised to consider the unique preferences of teenagers who are not active to increase their level of physical activity.

In line with the two previous studies before, Trail \& McCullough (2019) wrote a study on 'Sustainability of marketing through sports: testing the evaluation model of sports 
sustainability campaigns' written in the European Sport Management Quarterly (Taylor and Francis). Trail \& McCullough (2019) found important implications for sports managers and marketers as they created and advanced sports organizations' sustainability campaigns. Understanding the needs and values of sports participants can help marketers and managers determine how those needs and values can influence a positive attitude towards a campaign. Increase positive attitudes towards campaigns, while minimizing negative influences, so as to increase the success of sports organizations' sustainability campaigns. This model can be used to evaluate the effectiveness of sustainability campaigns to influence the attitudes and behaviour of sport participants.

In each of three previous studies, it is highly recommended to carry out campaigns on an on-going basis. In line with this research, it has the aim to provide education to the public with a sports science campaign. However, in all three studies, no one has carried out a sports science campaign through social media especially Instagram. This is the main topic that will be discussed in this study. How sports campaigns are carried out by students on Instagram social media in the form of assignments.

\section{Method}

This research was conducted with a quantitative survey method with a sample of 90 respondents from Palembang PGRI University students in a sports journalism course. Students are assigned to make information about sports science then observing for one month with 1 post per day. The results of this survey are to obtain information for researchers, to obtain an overview of the problems that will be the basis of sports campaign activities through social media. Information is obtained to see how students use social media, and how far social media can help students to share information with the public. Therefore, questions in the form of questionnaires were asked to students in the survey. Then, the results of the student posting assignments are analysed and categorized into positive or not reader responses by looking at the number of likes from the reader. Does the number of likes increase or decrease.

\section{Results and Discussion}

All observations that can be seen on the reality of sports information accounts on Instagram that many followers, get some opinions which according to researchers that this information is only about news about the score of the results of the game, seminar information, player selection information and many other things not focused on the science of technical sports and exercise. 
Picture 1: infoolahraga Instagram account

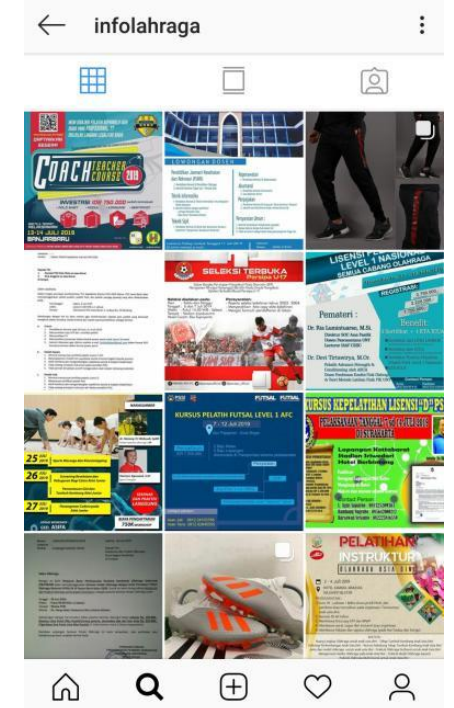

The Instagram account named by infoolahraga often shares the information for specific community who know about sport. This account does not give about sport science information like how to kick the ball on football competition, how to massage the muscle after exercise if got an accident, how to do a dribbling on basketball, etc. But this account is giving a light clue by information about seminar and workshop about sports. So, this account is little bit giving contribution in sport science campaign. In this research, this account is one of the student role models for carrying out sports campaign assignments.

Picture 2: garudarevolution Instagram account

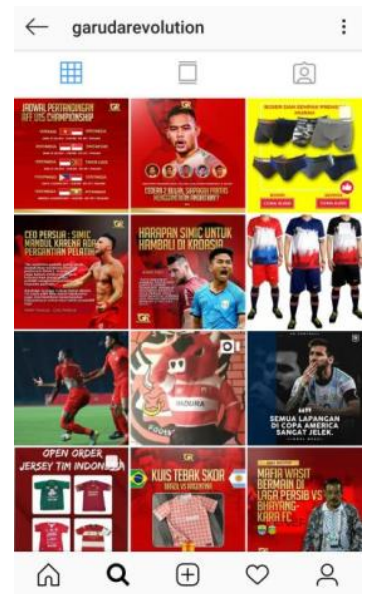

The garudarevolution Instagram account, shared the information for general community. This account shared about match results and football information even about Indonesia and the world wide football. So this account is rejected as the sample of this research because this account did not shared about sport science information. This research outcome is campaign sport science for community. The community should catch deep 
information about sport science. Based on the observations of these two accounts, it can be concluded that both accounts only convey information about sports. The account has not yet discussed the science of sport either in a basic or specialized manner.

Below is the result of the distribution of student questionnaires after carrying out sports campaign assignments. The number of respondents was 90 respondents.

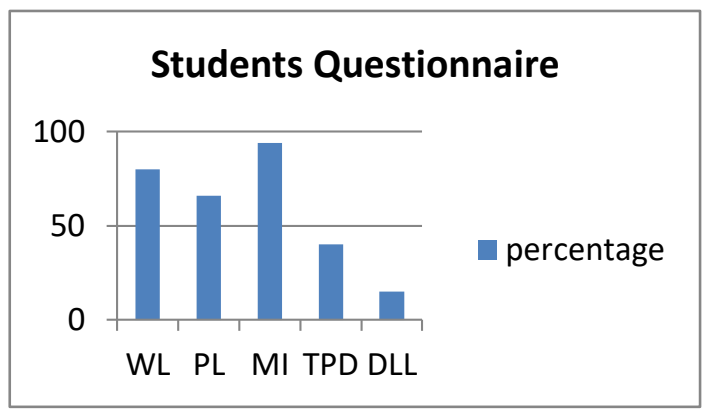

After carrying out the observations, this study is obtained results that explain that all students as respondents, namely as many as 90 respondents. All students have Instagram accounts. The results felt and obtained information through questionnaires are as many as $80 \%$ feel they have broad insight (WL), 66\% feel the relationship becomes wider (PL), 94\% feel a lot of getting information (MI), 40\% feel increased self-confidence (TPD), and others (DLL) as much as $15 \%$.

From the survey results through the questionnaire also got three categories of students using Instagram every day. The three categories of students are 15\% using Instagram in less than an hour, $30 \%$ are using Instagram for two hours and more than $65 \%$ are using Instagram for more than three hours.

\section{Campaign Design}

Achieving the mission of this research with the aim of many people can access sports science information in a social media account, especially Instagram. Based on Ellsworth's theory said that humans are connected or connected to each other through the internet network media. Using the internet on the positive side makes messages in social media an expanding knowledge of insights. In addition, according to Sirgy (1986) when a consumer is asked to remember information, the self-concept will actually have more role than the ideal selfconcept. In addition, Syaputri (2019) states that students need a way to harmonize languages. Included in this case is to spread positive information about the world of sports to the wider community requiring language alignment to be more organized. Therefore, in this campaign 
the group will put emphasis on the concept of true self which is the way teens look at themselves.

\section{Implementation}

The campaign was conducted on each student's Instagram for one month with duration of a day posting one sports news. In this campaign, each individual writes about basic technical sports knowledge, physical, mental condition or information about various definitions of each sport or sports term. This activity in order to highlight that the use of social media is not just the existence of a private collection but more about the benefit of using Instagram. Below is the example in writing Instagram poster in the form of "service below is one of the basic techniques in the volleyball game, where the service below is the initial blow to start a match (Abdul, Said, \& Pauweni, 2015)".

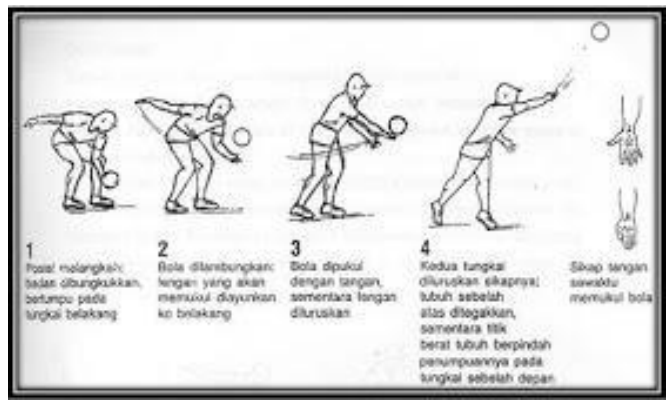

\section{Picture 3. Picture sample of sports science campaign assignment for a student}

The process of posting students observed and collected by looking at how the number of likes from each student account. Then the data on the number of likes is seen whether it will increase or not by monitoring the results of student reports every day about the task of sports science campaigns. Based on the results of student reports, only 15 students said they did not get a good response marked by the decreasing number of likes on sports science posts on social media Instagram. Furthermore, 75 students stated that there was an increase in the number of likes when compared to the initial and final posts regarding sports science posts. It can be concluded that, the sport science campaign on Instagram received positive responses from the wider community. The purpose of this campaign is to revive students that using media for information that can be useful for the public community on Instagram.

\section{Conclusion}

Based on the results of the study it can be concluded that, Instagram is a media that is very easy and interesting to use in introducing sports science through content that is loaded by 
Instagram account owners. But unfortunately very few Instagram accounts contain specific information about sports science. The average sports Instagram account only contains sports entertainment in the form of sports competition results updates containing no sports knowledge such as basic techniques, game strategies, match rules and more. Based on the results of the study it can be said that it has successfully carried out sports campaigns through social media Instagram with a total of 75 student accounts from 90 accounts with a success rate of 83 percent. The benefit of this campaign is to revive students that they can use social media wisely to provide information that can give deep benefit for community.

\section{Acknowledgement}

The greatest appreciation to all those who have helped the researcher completing this research, especially to the research participants. It is expected that everything poured in this study could give benefits for everyone.

\section{References}

Abdul, 1. D., Said, H., \& Pauweni, m. (2015). Meningkatkan Kemampuan Dasar Servis Bawah Pada Permainan Bola Voli Melalui Metode Drill Pada Siswa Kelas V SD Negeri 17 Telaga Biru. KIM Fakultas Ilmu Kesehatan dan Keolahragaan, 3(3).

Ghazali, M. (2016). Buat Duit Dengan Facebook dan Instagram: Panduan Menjana Pendapatan dengan Facebook dan Instagram. Malaysia: Publishing House.

Mutohir, T. C., \& Maksum, A. (2007). Sport Development Index. Jakarta: PT Indeks.

Nwankwo, G. O., \& Deemua, G. A. (2019). Sports: a Proactive Strategy for Educational Development. European Journal of Physical Education and Sport Science.

Palmer-Keenan, D. M., \& Bair, K. (2019). Research to Support the Development of a Campaign to Increase Physical Activity Among Low-Income, Urban, Diverse, Inactive Teens. Journal of nutrition education and behavior, 51(6), 703-710.

Riyanto, S. (2008). Rancang Bangun Database Terpusat Network Control System Pada Pt Bank Niaga Tbk Berbasis Web. Sekolah Tinggi Manajemen Informatika dan Komputer, Jakarta STI\& $K$.

Sirgy, M. J. (1986). Self-congruity: Toward a theory of personality and cybernetics. Praeger Publishers/Greenwood Publishing Group.

Syaputri, W. (2019). First Language Morphological Interference of English Language Learners (EFL). Seventh International Conference on Languages and Arts (ICLA 2018). Atlantis Press.

Tangkudung, J., \& Wahyuningtyas, P. (2012). Sports Coaching" Sports Performance Coaching. Jakarta, Smart Jaya.

Trail, G. T., \& McCullough, B. P. (2019). Marketing Sustainability Through Sport: Testing The Sport Sustainability Campaign Evaluation Model. European Sport Management Quarterly, 1-21.

World Internet Users Statistics and 2019 World Population Stats. (t.t.). Retrivied on July $18^{\text {th }}$, 2019, from https://www.internetworldstats.com/stats.htm 